\title{
Poetyka Ingardenowskich wspomnień hołdów oddawanych (nie tylko) fenomenologom
}

\section{Beata Garlej}

ORCID: OOOO-OOOI-8737-7924

(Uniwersytet Kardynała Stefana Wyszyńskiego w Warszawie)

To, co wiemy o innych, Jest tylko pamięcią tych krótkich chwil, W których ich znaliśmy ${ }^{\mathrm{I}}$

- ta skądinąd pesymistycznie wybrzmiewająca kwestia, którą wypowiada w dramacie T.S. Eliota postać Niezidentyfikowanego Gościa, znajduje dopełnienie w zanotowanych ręką Eugène’a Delacroix słowach: „Pamięć ludzka jest bardzo krótka: grzebie się równie szybko zdarzenia jak ludzi, którzy brali w nich udział”2, słowach odbierających popielatej melancholii Eliota światło, by wydobyć z niej dramatyzm głównej bohaterki tego artykułu: pamięci i jej właściwości. A że jest to w swej wieloznaczności bohaterka nieposkromiona, uświadamiają choćby myśli Delacroix, w innym miejscu stwierdzającego: „Pamięć odsłania miły moment lub daje niezbędne złudzenia”’ Która z jej odsłon - akcentująca dramatyczną kruchość czy może czyniąca z niej rezerwuar myśli na pewien czas zabalsamowanej, złudnie trwałej - patronuje wspomnieniowym w charakterze i przy rozmaitych okazjach prezentowanym lub publikowanym wypowiedziom polskiego filozofa Romana Witolda Ingardena? Oto najogólniej zarysowana kwestia, jaką pragniemy tu rozpatrzyć - niejedyna zresztą, metodologicznie bowiem dopiero otwierająca rozważania

1 T.S. Eliot, Cocktail party. Komedia (1950), w: idem, Cztery dramaty, tłum. W. Juszczak, red. przekładu i posłowie M. Heydel, Gdańsk 2016, s. 200.

2 E. Delacroix, Dzienniki. Częś́ druga (1854-1863), tekst franc. oprac. A. Joubin, thum. J. Guze, J. Hartwig, Gdańsk 2007, s. 148.

3 Ibidem, s. 239. 
i udostępniająca narzędzia służące zobrazowaniu we właściwym świetle sprawy podstawowej: poetyki Ingardenowskich wspomnień hołdów4

Podążając za wskazówką logicznego kompasu, moglibyśmy orzec, że bez założenia określonych walorów pamięci wspomnienia hołdy filozofa jawiłyby się niczym dryfująca tratwa bezcelowej i nieuzasadnionej refleksji, czyli ewenement (w) Ingardenowskiej myśli, zawsze przecież tak racjonalnej, precyzyjnie formułowanej, celowej... Skoro ręka autora Sporu o istnienie świata kreśliła także teksty upamiętniające, laudacyjne, nie sposób zignorować pytania: czego było to przejawem - wyłącznie duchowej, charakterologicznej dyspozycji filozofa, co jednak wpisywałoby się w standardowy schemat powielany przez wszystkich, którzy mają potrzebę upamiętniania innych, czy może odzwierciedlało prezentowaną subtelnie, w wyrafinowany sposób wykładnię własnego rozumienia fenomenu pamięci, jej walorów. A może jedno i drugie równocześnie, stopione ze sobą, a przez to udostępniające rzadki, gdy idzie o spuściznę fenomenologa, moment wyświetlania charakterologicznej osobowości blaskiem swojej koncepcji? Nie pokusimy się o dowiedzenie słuszności tezy zawartej w ostatnim pytaniu, wymagałoby to bowiem uwzględnienia biograficznych niuansów, w które obfituje życiorys Ingardena ${ }^{5}$. Obierzemy inną drogę: spróbujemy przede wszystkim naszkicować Ingardenowską wykładnię fenomenu pamięci. Okaże się w ten sposób - żywimy taką nadzieję - że wspomnienia hołdy przezeń tworzone urzeczywistniają określone teoretyczne dyrektywy fenomenu pamięci, Ingardenowskie ujęcia filozoficzne. Wyniknie z tych wspomnień, że poetyka nie stanowi celu sama w sobie, a ucieleśnia praktycznie teorię, przez co dopełnia tę wykładnię rozumienia pamięci. Tylko w takiej mierze, ograniczonej ramami wskazanej perspektywy, możliwe będzie odniesienie się również do zarzuconej przed momentem tezy dotyczącej związku między pisanymi przez Ingardena wspomnieniami hołdami a jego biografią, której nie sposób rzetelnie i szczegółowo rozważyć w ramach jednego artykułu.

4 W całym artykule zastosowano zapis „wspomnienie hołd” bez łączącego dywizu, ponieważ nie są to elementy równorzędne w określaniu Ingardenowskich tekstów (prym wiodą wspomnienia, które czasem intensywnie, czasem zaś bardzo subtelnie wchodzą w rolę hołdów).

5 W ostatnich latach sprawa ta jest zresztą czytelnikom pieczołowicie przybliżana dzięki publikacji korespondencji prowadzonej przez filozofa i jej omówień. Zob. Korespondencja Romana Witolda Ingardena z Kazimierzem Twardowskim, listy z oryginałów przeczytali, przepisali, opracowali oraz wstępem poprzedzili R. Kuliniak, D. Leszczyna, M. Pandura, Kęty 2016; Korespondencja Romana Witolda Ingardena. Z dziejów „Studia Philosophica. Commentarii Societatis Philosophicae Polonorum”, listy przeczytali, przepisali oraz wstępem poprzedzili R. Kuliniak, D. Leszczyna, M. Pandura, Ł. Ratajczak, Kęty 2018; Korespondencja Izydory Dąmbskiej z Romanem Witoldem Ingardenem, listy przeczytali, przepisali, opracowali oraz wstępem poprzedzili R. Kuliniak, D. Leszczyna, M. Pandura, Ł. Ratajczak, Kęty 2018. Niedawno ukazała się również pierwsza część biografii fenomenologa. Zob.

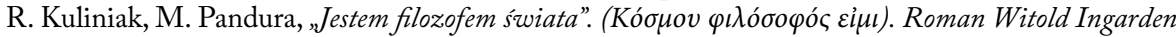
(1893-1970). Część pierwsza: lata 1893-1938, Kęty 2019. 
W 1938 roku na łamach „Muzeum. Czasopisma Pedagogicznego, Poświęconego Sprawom Wychowania, Nauczania i Organizacji Szkolnictwa" zostaje opublikowany tekst, którego tytuł zdradza ocenę wartościującą, podyktowaną (niewłaściwym) pojmowaniem naszej „bohaterki”-Lekceważenie pamięci ${ }^{6}$. Charakter periodyku, decyzja, by właśnie tam szkic ten umieścić, nie jest dziełem przypadku: Ingarden rozpatruje tu głównie dydaktyczny aspekt pamięci. Wychodząc od stwierdzenia o niewystarczającym stanie wiedzy zarówno wśród młodzieży kończącej etap edukacji w szkole średniej, jak i świeżo upieczonych absolwentów szkół wyższych, sygnalizuje właściwą im ulotność pamięci: „Jest ona na ogół bardzo mało obszerna, w znacznym stopniu niewierna, a co gorzej, o grom ni e nie trwała". Za zaistniały stan rzeczy winą obarcza nie tyle system edukacyjny, ile podwalinę, na której system ten się opiera: „główne prądy pedagogiki współczesnej n i e c e n i ą pa mię ci, więcej, wy raźn i e ją le kce wa żą jako jedną z władz duchowych"». Choć Ingarden w niejednej kwestii wypowiadał się kategorycznie, to w słowach tych zwraca uwagę utyskujący ton, rzadko pojawiający się w jego wywodach. Utyskiwanie to jednak niestandardowe, gdyż niepodyktowane chęcią toczenia na łamach periodyku jakichś sensacyjnych bojów $z$ bardziej lub mniej anonimowymi zwolennikami „prądów pedagogiki współczesnej”. Bierze się ono z subtelnie w szkicu nakreślonego rozumienia fenomenu pamięci, której związek $\mathrm{z}$ dydaktyką nie jest jedyny - to po pierwsze. Po drugie zaś, nawet jeśli najczęściej sprowadza się ją właśnie do aspektu dydaktycznego, to staje się on sensowny tylko z racji tego, czym pamięć sama w sobie (w rozumieniu filozofa) jest: „władzą duchową”. Mianem „kalek duchowych" określani są teraz ci, w których wychowaniu, kształceniu zignorowano rolę pamięci ${ }^{9}$. Co jednak ważniejsze - niemożliwością w Ingardenowskim ujęciu okazuje się rozwijanie moralnej, etycznej strony życia człowieka, jeśli pominąć ten rodzaj „władzy duchowej”. Podstawowy rys fenomenu pamięci dotyczy zatem tego, że jest on przede wszystkim możliwy do uzasadnienia etycznie, moralnie, a stąd już wniosek tylko jeden: bez uwzględnienia perspektywy aksjologicznej staje się praktycznie niewytłumaczalny.

Trywialność zaprezentowanego wyżej stwierdzenia może wywołać konsternację. Idzie jednak o zwrócenie uwagi na podstawową zależność, która z niego wynika. Otóż w świetle fenomenu pamięci - „władzy duchowej” czynność wspominania jest obciążona aksjologicznie i uruchamia swoistą selekcję rozpat ryw a nia

6 Zob. R. Ingarden, Lekceważenie pamięci, „Muzeum. Czasopismo Pedagogiczne, Poświęcone Sprawom Wychowania, Nauczania i Organizacji Szkolnictwa” 1938, R. LIII, s. 8-18.

7 Ibidem, s. 9.

8 Ibidem, s. 11.

9 Zob. ibidem, s. 14. 
s p r a w, które się nim (wspominaniem) obejmuje. Mówiąc inaczej, a zarazem nieco trywializując, trzeba zasłużyć sobie na to, by być wspominanym, i to nie byle czym. Choć zabrzmi to patetycznie, zasługą taką jest na polu nauki i w rozumieniu Ingardena nie tylko wpływanie na odbiorców pod względem poznawczym, ale także kształtowanie ich rozwoju duchowego. Jeśli w miejsce wymienionych wcześniej „spraw” podłożyć życiorysy ludzi, to okaże się, że niegdysiejszej Ingardenowskiej czynności celowego, podyktowanego aksjologiczną premedytacją wspominania zawdzięczamy materializację określonego wytworu: wspomnień będących jednocześnie hołdami złożonymi tym, którzy przede wszystkim (choć niewyłącznie) swoją pracą, swoimi naukowymi osiągnięciami potrafili duchowo rozwijać innych ${ }^{\mathrm{IO}}$.

Poetyka Ingardenowskich wspomnień hołdów służy ukazaniu pamięci tak, jak pojmował ją filozof, a więc w roli „władzy duchowej” rozwijającej etycznie, moralnie ${ }^{\mathrm{II}}$. Czy ma ona jakieś sobie tylko właściwe cechy formalne? A może realizuje konkretny schemat kompozycyjny? By pokusić się o sformułowanie odpowiedzi wyłącznie na te pytania, zasadne byłoby po prostu przejść do analizy rzeczonych wspomnień hołdów. $\mathrm{Z}$ uwagi na określone rozumienie fenomenu pamięci nie tyle stricte filologiczna, czyniona ze względu na właściwości stylistyczne czy postać kompozycyjną, ile szerzej pojęta jego interpretacja wytyczy ramy naszych dalszych rozważań. Wytyczy je właściwie co innego, a mianowicie próba odpowiedzi na pytanie o to, czy (a jeżeli tak, to w jakim zakresie) język Ingardena jako fenomenologa, język fenomenologicznego wglądu „wnika” w poetykę jego wspomnień hołdów i w jakiej mierze przyczynia się do (nie)usprawnienia pamięciowego przekazu ${ }^{\text {I2 }}$. Takie postawienie sprawy powoduje,

$10 \mathrm{Z}$ treści krakowskiego Wyktadu drugiego (12 października 1961) wynika, że podnoszoną tu przez nas kwestię lokował ostatecznie w polu niezmiernie skomplikowanego zagadnienia „w y s o k o śc i, czy też st o p n i a, czy wa r to śc i o wo ści czegoś (życia, honoru, ambicji)”, którego wyartykułowanie zostało poprzedzone znamiennymi słowami: „Czyje życie jest więcej warte z jakiegoś punktu widzenia (z punktu widzenia kultury, z punktu widzenia twórczości)? Jakoś jednak decydujemy, szybko albo nie szybko, albo zbyt powoli, tak że potem można w ogóle nie decydować, bo już przeszła okazja do tego, żeby coś zrobić”, w: idem, Wyktady z etyki, wybrał, oprac. i wstępem poprzedził A. Węgrzecki, Warszawa 1989, s. 136.

11 Nie zapominajmy, że wniosek ten jest podyktowany perspektywą wyznaczoną także formalnymi możliwościami tekstów okolicznościowych: wspomnień hołdów. W innym świetle prezentuje się bowiem rozumienie pamięci, jeśli uwzględnić rozważania syntetyczne, zawarte choćby w jego rozprawie doktorskiej. Zob. R. Ingarden, Intuicja i intelekt u H. Bergsona. Przedstawienie teorii i próba krytyki, z języka niem. tłum. M. Turowicz, w: idem, Z badań nad filozofiq wspótczesna, Warszawa 1963, s. 9-191.

12 Posiłkując się słowami Jacka Migasińskiego, wyartykułujmy podstawowy fakt uzasadniający naszą metodologię działań: „Fenomenologia czyniąca zasadniczym obiektem swych analiz zjawiska związane $z$ przypominaniem sobie, zapominaniem, przechowywaniem wspomnień itp., krótko mówiąc - $\mathrm{z}$ szeroko rozumianą pamięcią, jest $-\mathrm{z}$ jednej strony - pewną wyodrębnioną dziedziną fenomenologii, pewną fenomenologią regionalną. $Z$ drugiej jednak strony fenomenologia pamięci - poprzez swoje konieczne ugruntowanie $\mathrm{w}$ fenomenologii czasu [...] przybiera $\mathrm{w}$ takim aspekcie charakter dziedziny fundamentalnej dla filozofii po prostu, a przynajmniej dla jej problematyki ontologicznej i epistemologicznej" (J. Migasiński, Przyczynek do zarysu francuskiej fenomenologii pamięci. Trzy przy$k t a d y$, ,Fenomenologia. Pismo Polskiego Towarzystwa Fenomenologicznego” 2006, nr 4, s. 89). 
142

że konieczne jest - choćby zdawkowe - odniesienie się do kwestii pierwszorzędnej: języka filozoficznego, konkretnie zaś właściwości języka fenomenologów.

W wywiadzie rzece z uczniem Ingardena, Władysławem Stróżewskim, pojawia się znamienny dla obecnego wątku naszych rozważań fragment, który choć obszerny treściowo, wart jest przytoczenia:

》- Jako filozof uznaje Pan możliwość dojścia poprzez język do prawdy o rzeczywistości, do prawdy bytu?

- Ależ tak. Na dobrą sprawę każdy filozof wypracowuje swój własny język, choć ja nie traktowałem nigdy języka jako przedmiotu, od którego wszystko się zaczyna i na którym wszystko się kończy. Przywiązuję dużą wagę do języka w innym wymiarze: nie akceptuję polszczyzny byle jakiej.

$[\ldots]$

- Dotykamy tu istoty języka w filozofii i dla filozofii.

- Kwestia precyzji języka filozoficznego i tego, na czym polega jego adekwatność w stosunku do rzeczywistości, to jedno z najważniejszych i najtrudniejszych zagadnień. Jeśli w języku naukowym ważna jest ścisłość językowa polegająca na tym, że jedno z drugiego wypływa wedle takiej czy innej reguły, to w filozofii ważna jest precyzja języka. Chodzi o to, by nie był wieloznaczny.

- Na czym polega różnica?

- W filozofii nie chodzi o to, by być purystą językowym. Jeśli jest potrzebne porównanie, to nie należy wahać się z jego użyciem. Podobnie z metaforą. Przypatrzmy się Platonowi. On to doskonale opanował. Wiedział dokładnie, kiedy jej użyć. [...] Można posługiwać się językiem dosyć prostym, ale bardzo nośnym. Można też iść w kierunku wyznaczonym przez neopozytywizm i precyzować ścisłe reguły poprawności języka w nauce. Wciąż jednak pamiętam, jak Ingarden podkreślał, że najlepszy dla filozofii jest język potoczny, że to w nim da sięnajwięcej p ow i e d z i e ć [wyróżn. B. G.], a jeżeli trzeba coś dopracowywać, to należy to zrobić, zaznaczając jednak wyraźnie, że teraz nie będę mówił językiem potocznym, tylko bardziej technicznym - „nazwijmy to tak i tak"'s3. 
Można by uznać, że przywołany fragment w najmniejszym stopniu nie odnosi się do rozpatrywanej przez nas kwestii, czyli do próby wyświetlenia specyfiki tych tekstów okolicznościowych autorstwa Ingardena, które pracami filozoficznymi nie są. Nie można jednak pominąć i tego banalnego faktu, że w czasie ich pisania Ingarden nie przestał być filozofem i fenomenologiem. Takie, a nie inne rozumienie fenomenu pamięci wraz z uprzywilejowaniem języka potocznego, gdy idzie o sprawność filozofowania w ogóle, dostarcza klucza deszyfrującego poetykę tworzonych przezeń tekstów okolicznościowych. Klucz ten sprowadza się właściwie do maksymy - której istotę oddaje również myśl Delacroix - zawierającej się w słowach: „Zasługą jest mówić rzeczy piękne, ale nade wszystko trzeba być zrozumiałym. W przeciwnym razie język, miast być niewolnikiem pisarza, staje się jego tyranem, któremu poświęca on co najciekawsze w utworze, to znaczy sens" ${ }^{\text {I4 }}$. $Z$ pewnością Ingardenowskie wspomnienia hołdy są świadectwem tego, że ich autor nie dał się zniewolić językowi, nie poddał urokowi zdobień, stylistycznej ornamentyki, której mogłoby nadużywać wielu innych autorów $\mathrm{z}$ racji tworzenia tekstu o charakterze upamiętniającym. Stykamy się wręcz z odmienną sytuacją - poetyka tych prac odzwierciedla właściwości języka fenomenologów przetransponowane na inną sytuację komunikacyjną niż tworzenie tekstu filozoficznego, co było wielekroć i w różnych wariantach realizowane, a na co zwrócił uwagę między innymi Mario Sancipriano w omawianym już przez nas niegdyś studium ${ }^{\mathrm{I} 5}$. Kompozycyjny schemat wspomnień hołdów, ich cechy formalne są wypadkową stosowalności metody fenomenologicznego filozofowania, przede wszystkim opierającego się na rozumowaniu dedukcyjnym („od ogółu do szczegółu”). Najwyższy czas przejść do analizy konkretnych Ingardenowskich tekstów tego rodzaju, by bardziej szczegółowo zdać sprawę ze specyfiki poetyki, z jakiej wyrosły.

Autor Das literarische Kunstwerk objął wspomnieniami hołdami osoby, których myślowy dorobek wywarł na nim znaczny wpływ bądź nawet zaważył na jego drodze badawczej. Byli to zarówno filozofowie, reprezentanci nurtu, z którym sam się identyfikował (fenomenologia) - przede wszystkim jego mistrz Edmund Husserl, poza tym poznana w związku z podjętymi w Getyndze studiami Edith Stein, jedna z najzdolniejszych uczennic Husserla, czy wreszcie zainspirowany Husserlem, zanurzony w problematyce etyki i aksjologii Max Scheler - jak i niebędący fenomenologami: cieszący się uznaniem Husserla Kazimierz Twardowski i jego uczeń Zygmunt Zawirski, Mścisław Wartenberg (metafizyk, znawca Kanta),

2017, s. 121-122.

14 E. Delacroix, Dzienniki. Częś́ druga..., s. 158.

15 Zob. M. Sancipriano, Le langage de la création esthétique dans la phénoménologie, „Analecta Husserliana" 1991, t. XXXIII, s. 281-293. Zob. też: B. Garlej, O (podstawowym) znaczeniu Ingardenowskiej kategorii konkretyzacji estetycznej, Kraków 2018, s. 84-85. 
ksiądz Konstanty Michalski (historyk filozofii, twórca perfekcjonaryzmu), teoretycy sztuki, artyści (Leopold Blaustein, Stanisław Ignacy Witkiewicz, Zygmunt Łempicki). Zważywszy na chronologię powstania i publikacji tych tekstów, widzimy wyraźnie, że wyszły spod pióra człowieka dojrzałego, obeznanego nie tylko z europejskim środowiskiem naukowym, ale i szczególnie dobrze zorientowanego w życiu kulturowym własnej epoki. Niemniej chronologia nie ukierunkuje biegu naszej analizy, a istotne okaże się to, na co wcześniej wskazaliśmy: fakt wyzyskania metody fenomenologicznego filozofowania w celu wytyczenia schematu kompozycyjnego tekstu okolicznościowego, który każdorazowo opiera się na „częściach stałych”, odmiennie jednak przez Ingardena hierarchizowanych i z tej przyczyny mających różną, bardziej bądź mniej wyrazistą, stylistyczną postać. Modelowym przykładem tak powstałej kompozycji wspomnienia hołdu jest artykuł z „Tygodnika Powszechnego" poświęcony księdzu Konstantemu Michalskiemu, do którego omówienia obecnie przejdziemy ${ }^{16}$.

Już początkowe fragmenty tego tekstu operują zderzeniem mikro- i makroskali zasięgu spraw - Ingarden szybko zdradza przeznaczenie omawianego wspomnienia: „dobrze jest, choćby w kilku zdaniach uświadomić sobie, kim był i czego dokonał [ksiądz Michalski - B. G.], i uczcić tym Jego pamięć”’7. I nie byłoby w tej deklaracji biograficzno-twórczego zobrazowania nic dziwnego, gdyby nie kolejny ustęp, na pierwszy rzut oka wyłącznie burzący ciągłość harmonijnie dopiero co zapowiadanej refleksji, będący jednak rozważaniem bardzo ogólnych zagadnień, w których mowa jest o powstaniu „nowoczesnej, świadomej naukowej odpowiedzialności filozofii polskiej”. Dochodzi tutaj do porównania tej ostatniej z europejską, napomyka się również o polskim języku filozoficznym, zależnym od określonych przedsięwzięć - krajowych zjazdów i czasopism filozoficznych ${ }^{\mathrm{I}}$. Tak rozległa, panoramiczna perspektywa, budząca wręcz podejrzenie o rozminięcie się autora tekstu $z$ tematem, stanowi chwyt, za pomocą którego filozof bardzo zgrabnie i przy udziale percepcji najmniej teraz spodziewającego się tego czytelnika - otumanionego horyzontem refleksji ogólnej - atakuje samo jądro sprawy. Oto w kolejnym ustępie uczeń Husserla nieoczekiwanie podsumowuje refleksję o bogatej, skomplikowanej tradycji filozoficznej zarówno rodzimej, jak i europejskiej, by na podstawie pozyskanego w ten sposób zestawu twierdzeń zdać sprawę już wyłącznie z jednego: co na tym tle zawdzięczamy dorobkowi myślowemu księdza Michalskiego.

16 Zob. R. Ingarden, Ks. Konstanty Michalski. Uczony - filozof - cztowiek, „Tygodnik Powszechny. Katolickie Pismo Społeczno-Kulturalne" 1947, nr 34 (127), s. 1-2. W cytatach zachowano pisownię oryginału, natomiast zmodernizowano interpunkcję.

17 Ibidem, s. 1.

18 Ibidem. Cytowany fragment przekształcono gramatycznie w celu dostosowania do składni wywodu. 
Mechanizm zastosowanego chwytu, oparty na zderzeniu dwu perspektyw (ogólnej i indywidualnej), jest w swojej celowości nad wyraz oczywisty - to Ingardenowski probierz, służący teraz podkreślaniu rangi spuścizny bohatera jego tekstu. Mechanizm rozpostarty na „częściach stałych”, charakterystycznych także dla pozostałych Ingardenowskich wspomnień hołdów, a są nimi: I. zestawienie i rekonesansowe omówienie prac księdza (uporządkowane nie tyle chronologicznie, ile przez wzgląd na dominujący motyw problemowy, merytoryczny), na tej podstawie wyprowadzona 2. identyfikacja naukowa („Ks. rektor Michalski był historykiem filozofii w nowożytnym tego słowa znaczeniu”" ${ }^{\text {"9 }}$ ), i wreszcie, już finalnie, na jej fundamencie czyniona 3. charakterystyka stricte osobowościowa, zwieńczona 4. konkluzją - aksjologiczną oceną księdza, w pierwszej kolejności uwzględniającą go jako obdarzonego takimi, a nie innymi walorami osobowościowymi, dopiero w dalszej kolejności obejmująca cechy Michalskiego jako naukowca (warunkowane jednak przez jego osobowość). Dla poetyki omawianego tekstu okolicznościowego jest przy tym znamienne, że kompozycyjnie uzasadnione przejście między drugim a trzecim elementem - „częścią stałą” - dokonuje się wskutek bezpośredniego odniesienia do problematyki stricte esencjalnej, przez Ingardena rozpatrywanej niegdyś we własnej rozprawie habilitacyjnej ${ }^{20}$. Ten fragment wspomnienia hołdu, zdecydowanie najbardziej trącący stylistyką zaprezentowanego wówczas wywodu, z logiczną premedytacją argumentuje zasadność obdarzenia księdza Michalskiego konkretnym epitetem, dalej odnoszonym do każdej z płaszczyzn jego identyfikacji: w świetle naukowej zyskuje miano „dojrzałego filozofa”, w świetle zaś osobowościowej - mówi się o nim jako o „człowieku prawdziwie dojrzałym”. Nie mogą zatem dziwić słowa konkluzji - oceny aksjologicznej: „Był człowiekiem, który i dorobkiem swoim naukowym, i tym, co zdołał w sobie samym życiem swym zbudować, pozostanie trwałą war to ści ą [wyróżn. B. G.] w kulturze duchowej Polski i Człowieczeństwa”"

Osadzone już nie tyle w faktografii rzeczywistości (kulturowej) w ogóle, ile wytyczone meandrami konkretnej biografii, odsłaniającej zwłaszcza aktywność naukową, są te wspomnienia hołdy, których główny rys kompozycyjny Ingarden - teraz jednak w zakamuflowany sposób - wyprowadza również z metody fenomenologicznego filozofowania wspartego na dedukcji. Odzwierciedlają to szczególnie dwa teksty - jeden poświęcony Leopoldowi Blausteinowi ${ }^{22}$, drugi upamiętniający Zygmunta

19 Ibidem.

20 Zob. R. Ingarden, O pytaniach esencjalnych, w: idem, Z teorii jezyka i filozoficznych podstaw logiki, Warszawa 1972, s. 327-482.

21 Idem, Ks. Konstanty Michalski..., s. 2.

22 Zob. idem, Leopold Blaustein - teoretyk radia i filmu, „Zeszyty Prasoznawcze” 1963, R. IV, nr 3 (17), s. $86-88$. 
Zawirskiego ${ }^{23}$. Schemat kompozycyjny obu opiera się dokładnie na tych samych co poprzednio „częściach stałych”, są one jednak, jak już wcześniej stwierdziliśmy, inaczej hierarchizowane, i bynajmniej nie idzie tu wyłącznie o czysto formalną zmianę kolejności ich następstwa.

Kompozycyjne, ale i stylistyczne pokrewieństwo, jeśli porównać dopiero co przenalizowany tekst $\mathrm{z}$ obecnie wymienionymi, $\mathrm{w}$ większym stopniu dotyczy tego pierwszego, nieokreślonego właściwie nawet jako wspomnienie hołd ${ }^{24}$. Choć można zaobserwować w jego obrębie zmianę szyku „części stałych”, to nie urasta ona do rangi jakiegoś całościowego przetasowania ${ }^{25}$ - identyfikacja naukowa (Blaustein to przede wszystkim „opisowy psycholog”) poprzedza zestawienie jego prac, ale i tutaj bohater tekstu zyskuje dokładnie ten sam epitet (zostaje uznany najpierw za „dojrzałego” studenta, a finalnie - za „dojrzałego człowieka i dojrzałego uczonego”). Słowa konkluzji wybrzmiewają jednak dość niejednoznacznie: „mógł pozostawić trwałe śl a dy [wyróżn. B. G.] swej działalności w umysłowości polskiej. Że do tego nie doszło, sprawił to ciężki los, jaki przypadł jego pokoleniu w udziale. Ale jeżeli nawet dzieło jego życia nie uzyskało tej postaci, do jakiej z pewnością by było dojrzało, gdyby był przeżył wojnę, to i tak dorobek jego naukowy nie jest bez znaczenia i nie powinien być zapomniany ani zmarnowany" ${ }^{26}$. Co je uzasadnia? Zważywszy na okoliczności śmierci „w obozie na Janowskim we Lwowie, gdzie zginął wraz z żoną i synkiem”²7, uzmysławiają, że „dojrzałość” dorobku Blausteina została dramatycznie przerwana, a jako niespełniona nie była też zdolna ukonstytuować wartości trwałej „dla”- kształtowania, rozwoju kolejnych pokoleń. Formuła

23 Zob. idem, Wspomnienie o prof. Zawirskim, „Dziennik Literacki” 1948, R. II, nr 18 (61), s. 7.

24 Formalnie rzecz biorąc - i jak podkreślają to redaktorzy „Zeszytów Prasoznawczych” - tekst Ingardena funkcjonuje $\mathrm{w}$ roli słowa wstępnego, gdyż poprzedza publikację jednego z rozdziałów pracy Blausteina na łamach wskazanego periodyku. Zob. Idem, Stuchacz samotny, czy publiczność radiowa?, „Zeszyty Prasoznawcze” 1963, R. IV, nr 3 (17), s. 88-93. Niemniej Ingardenowski tekst zawiera każdą z „części stałych”, pozwalających zidentyfikować go jako wspomnienie hołd.

25 Bardziej radykalną zmianę w tym względzie możemy zaobserwować we wspomnieniu hołdzie poświęconym profesorowi Zawirskiemu, w którym dominującą częścią, wręcz pochłaniającą charakterystykę osobowościową, okazuje się zestawienie i omówienie jego najważniejszych prac oraz zaprezentowanych w nich założeń. Kompozycyjna dominanta tego elementu jest jednak domknięta lapidarną formułą określającą typ osobowości profesora - zdaniem Ingardena ten uczeń Twardowskiego „odznaczał się bezwzględnym oddaniem pracy naukowej i pracą tą wyłącznie żył” (R. Ingarden, Wspomnienie o prof. Zawirskim, s. 7). Na zgoła przeciwległym biegunie, teraz z kolei z charakterystyką osobowościową w roli kompozycyjnego hegemona, plasuje się tekst poświęcony Witkacemu. Zob. idem, Wspomnienie o Stanistawie Ignacym Witkiewiczu, w: Stanistaw Ignacy Witkiewicz. Cztowiek i twórca. Ksiega pamiqutkowa, red. T. Kotarbiński, J.E. Płomieński, Warszawa 1957, s. 169-176. Z jeszcze bardziej skomplikowaną sytuacją stykamy się w wypadku tekstu $O$ badaniach filozoficznych Edith Stein, który kompozycję wspomnienia hołdu niejako osadza w trybach referowania dorobku Stein, a więc w pryzmacie jednej „części stałej”. Zob. idem, O badaniach filozoficznych Edith Stein, w: E. Stein, O zagadnieniu wczucia, tłum. D. Gierulanka, J.F. Gierula, Kraków 1988, s. 155-180. 
„wartości trwałej”, o jaką zostaje wzbogacona ocena aksjologiczna wspomnienia hołdu księdza Michalskiego, w tym wypadku wybrzmieć nie może, stąd i już nie tak uroczysta w retorycznym wydźwięku konkluzja. Nie podważa ona jednak statusu tego tekstu jako wspomnienia hołdu. Dzieje się wręcz przeciwnie, co jest podyktowane szczególną, niecodzienną sytuacją, w jakiej nauczyciel i mistrz składa niegdysiejszemu uczniowi „tekstowy pokłon”. Ta nietypowa, wyjątkowa okoliczność każe zwrócić uwagę na fakt w tym momencie bodaj najdonioślejszy: brak osiągnięcia naukowej pełni przez Blausteina to dla fenomenologa kwestia ważna, ale w istocie drugorzędna - Ingardenowskie wspomnienia hołdy są konsekwencją uznania wartości drugiego jako człowieka, osoby. Motywacji ich powstania nie można żadną miarą sprowadzać jedynie do wartości selekcjonującej, wynikłej z wykonywania przez kogoś określonej profesji, trudnienia się taką, a nie inną naukową specjalizacją. A niewątpliwie za kogoś takiego - człowieka dojrzałego - Blaustein uchodził w oczach filozofa.

Wspominamy tych, którzy odeszli - przede wszystkim krewnych, przyjaciól, ale także ludzi, z którymi łączyły nas jedynie czysto zawodowe relacje, bądź tych, z którymi kontakt dotyczył tylko wycinka naszej codzienności, czasem zupełnie drobnego, wydawać by się mogło - nieistotnego. Czy każde wspomnienie jest jednak hołdem? Z perspektywy filozofii fenomenologicznej, pojętej czysto potocznie, bez wdawania się w niuanse pojęć i założeń konkretnego reprezentanta tego nurtu, niełatwo na to pytanie odpowiedzieć. Należy wszak uznać, że nie każde wspomnienie ma status hołdu, może być ono bowiem rozumiane jako przejaw nakierowania intencji, myśli „na” to, co było, co wcale nie musi oznaczać odniesienia się „do” czegoś niejako automatycznie pozytywnie wartościowego - możemy przecież wspominać także ludzi, którzy w naszej pamięci zapisali się zgoła niechlubnie. Wywołana biografią Blausteina okoliczność tragicznej śmierci eksponuje jednak taki horyzont uznania wartości drugiego człowieka, który może być jedynie hołdem - tu konkretnie przyjmującym postać „pokłonu zwerbalizowanego”.

Odbierająca czyjeś „tu i teraz”, przez co w pewnym stopniu zawsze tragiczna, bo związana ze stratą, śmierć stanowi kanwę ogólu wspomnień hołdów filozofa, tworzonych i publikowanych zarówno w krótkim przedziale czasowym od chwili, w której zaszła („Przed kilku dniami umarł Mścisław Wartenberg, honorowy profesor filozofii Uniwersytetu J. K. we Lwowie" ${ }^{28}$ ), jak i przeciwnie - z odległej, liczonej w dekadach perspektywy („Gdy dziś, dwadzieścia lat po jego [Zygmunta Łempickiego - B. G.] tak przedwczesnej, tragicznej śmierci, patrzy się na jego

28 R. Ingarden, Mścistaw Wartenberg, „Dziennik Polski” 1938, R. IV, nr 111, s. 6. Numer ukazał się w niedzielę, 24 kwietnia, a więc nieco ponad tydzień od śmierci filozofa, która nastąpiła 13 kwietnia, opublikowano poświęcony mu tekst Ingardena. 
$\mathrm{I} 48$

dorobek naukowy $\left.[\ldots]^{\prime 29}\right)$. W ich poetyce daje się przy tym dostrzec zróżnicowanie stopnia natężenia, z jakim tę kanwę się przywołuje. Przejawem tego jest odmienna postać epitetów - o ile we wcześniejszych hołdach można było obserwować dbałość o występowanie konkretnego, najbardziej adekwatnego (i z reguły jednego) epitetu niezbędnego do sformułowania konkluzji - oceny „aksjologicznej”, o tyle w tekstach poświęconych Wartenbergowi, Łempickiemu czy wreszcie Schelerowi dzieje się wręcz na odwrót - stykamy się ze swoistym bogactwem urodzaju w tym zakresie: epitety są nie tylko różne, ale budują całe ciągi przydawkowych dopowiedzeń. Wartenberg więc to „świetny wykładowca”, „samotnik, zagłębiony w świat własnych zagadnień”, „znakomity znawca filozofii Kanta”, ale i „umysł syntetyczny” odznaczający się „samodzielnością i odwagą"3․ Łempicki - „człowiek tak niezmiernie ruchliwy, rzucający się w najróżnorodniejsze imprezy literackie i praktyczne, nie mający nigdy czasu - jak by się wydawało - na spokojną wielogodzinną dyskusję naukową, zawsze jakby uplątany w bieg spraw, których motorem był on sam, zawsze jakby tylko dorywczo pracujący, nie mogący niczego spokojnie doprowadzić do końca, bo niosła go fala namiętności intelektualnych [...]”3 Scheler - „był jedną z najbogatszych umysłowości współczesnych Niemiec, a może i Europy. [...] należy żałować, że najbardziej uzdolniony z pośród uczniów Husserla stał się ostatecznie wielkim niebezpieczeństwem dla dalszego rozwoju badań fenomenologicznych, dając nieraz przykłady, jak analiz fenomenologicznych przeprowadzać nie należy [...]”32. Co odzwierciedlają te wspomnienia? Żywiołowość Ingardenowskiego języka, rozluźniającą formalnie układ „części stałych”, dotąd sztywno kompozycyjnie okopanych na swoich pozycjach, teraz zdających się wzajemnie przenikać. A wszystko podyktowane czysto życiową okolicznością: im dłużej, ale w szczególności bliżej, zwłaszcza prywatnie, filozof kogoś znał, tym większy gromadził arsenał wspomnień, wyświetlających czasem bardzo różne cechy osobowościowe jednego, lecz wciąż tego samego człowieka.

Język Ingardena, choć wykorzystujący w strukturze tekstu jedną metodę, zmienia się: do rozbudowanych epitetów dołączają, wprawdzie rzadko, pozbawione wy-

29 Idem, Zygmunt Łempicki jako teoretyk literatury, w: idem, Studia z estetyki, t. III, Warszawa 1970, s. 404.

30 Cytowane określenia przeformułowano gramatycznie w celu dostosowania do składni wywodu. Ostatnie z nich jest wnioskiem Ingardena odnoszącym się do konkretnej publikacji profesora. Zob. M. Wartenberg, Obrona metafizyki. Krytyczny wstęp do metafizyki, Kraków 1902.

31 R. Ingarden, Zygmunt Eempicki..., s. 402.

32 Idem, Max Scheler (29.VIII.1874. - 19.V.1928.), „Przegląd Filozoficzny” 1928, R. 31, z. IV, s. 350-351. Zaznaczmy, że Ingarden sześć lat wcześniej opublikował tekst-omówienie jego dorobku myślowego. Pisząc o poglądach wówczas żyjącego filozofa, posługuje się językiem niestroniącym od metafor, przy czym i w tym wypadku wyrazisty jest ton podporządkowany fenomenologicznej obserwacji, ale i dbałość o wypracowanie maksymalnie obiektywnej opinii, niepodyktowanej faktem zadzierzgnięcia prywatnej z nim znajomości. Zob. idem, Max Scheler, „Przegląd Warszawski”1922, t. IV, nr 13, s. 5-31. 
myślności metafory, które z pierwotnie jednowymiarowego poziomu kompozycji czynią z niej coś na kształt wielowymiarowego konglomeratu „części stałych”. Jakby wspomnienie hołd także (zwłaszcza!) swoją budową, stylistycznym urozmaiceniem miało oddać fakt wielości wspomnień łączących Ingardena $\mathrm{z}$ tym, komu taki tekst poświęca. Tak wyjątkowymi tekstami, pierwotnie wygłaszanymi, są wspomnienia hołdy oddane Kazimierzowi Twardowskiemu i Edmundowi Husserlowi33 ${ }^{33}$, myślicielom, którzy bez wątpienia odegrali najbardziej doniosłą rolę nie tylko w twórczym życiu filozofa. Oddajmy jeszcze na moment głos badaczom-filozofom: „Ingarden przeżył oczywiście zarówno Husserla, jak i Twardowskiego. Znamienne jednak pozostaje jego zachowanie. W chwili gdy niemal w tym samym momencie w 1938 roku Twardowski wraz z Husserlem odeszli i przekroczyli «brzegi Styksu», zachował on wobec nich «wielki gest» i pamięć w sercu wielkiego polskiego filozofa!" ${ }^{4}$. Nie ma tu miejsca na szczegółową analizę, dookreślającą wyjątkowość właśnie tych Ingardenowskich wspomnień hołdów, będących, jeśli wesprzeć się na przytoczonych słowach, przejawem osobliwej, bo zakotwiczonej w samych uczuciach Ingardena, pamięci. Już wyłącznie na jedno chcemy zwrócić uwagę. Otóż konkluzje obu tekstów nie ustanawiają również standardowej oceny aksjologicznej, gdyż eksponują przede wszystkim wartość, o którą ci dwaj, zdaniem Ingardena - niezmordowanie, zabiegali: prawdę. Podobnie jak w życiu prawda wyłania się z wielości perspektyw, nie przestając być sobą, tak językowo zdolna jest tę jej właściwość identyfikowania człowieka najsprawniej oddać poetyka tekstu - wielowymiarowa w kompozycyjnym wariancie - w której nie ma już prostego szeregu „części stałych”, a jest ich cała wzajemnie uzasadniająca się kawalkada.

Poetyka Ingardenowskich wspomnień hołdów służy oddaniu świata myśli skierowanej ku ludziom zapamiętanym, a więc ważnym. Skłania się ku wartościom, w które zdołali oni nie tyle wzbogacić rzeczywistość, ile przede wszystkim uczynić ją bardziej zrozumiałą dla innych. Jest poetyką szczególną, bo choć zwerbalizowaną, to od języka niewychodzącą i niewarunkowaną językiem - bierze się z czyjejś obserwacji i czyjegoś rozumienia rzeczywistości przez ludzi ją współtworzących, starając się we wspomnieniowym przekazie zdać jak najwierniej sprawę z tego, co najbardziej skomplikowane - z prawdy o człowieku.

33 Zob. idem, Dziatalność naukowa Kazimierza Twardowskiego, w: idem, Z badań nad filozofia wspótczesna, Warszawa 1963, s. 253-265 (w dopisku figurującym pod treścią tekstu czytamy, że było to: „Przemówienie wygłoszone na Akademii Żałobnej we Lwowie, w dn. 30 kwietnia 1938”); idem, Przemówienie radiowe na stulecie urodzin Edmunda Husserla, w: idem, Z badań..., s. 623-628 (tu z kolei w pierwszym przypisie widnieje informacja: „Jest to przemówienie radiowe wygłoszone w Norddeutscher Rundfunk w Hamburgu 9 kwietnia 1959 r. za pośrednictwem Polskiego Radia w trakcie wieczoru poświęconego Husserlowi”).

34 R. Kuliniak, D. Leszczyna, M. Pandura, Wstęp, w: Korespondencja Romana Witolda Ingardena z Kazimierzem Twardowskim, s. 151. 


\section{BibliogRAFiA}

Blaustein L., Stuchacz samotny, czy publiczność radiowa?, „Zeszyty Prasoznawcze” 1963, R. IV, nr 3 (17).

Delacroix E., Dzienniki. Częś́ druga (1854-1863), tekst franc. oprac. A. Joubin, tłum. J. Guze, J. Hartwig, Gdańsk 2007.

Eliot T.S., Cocktail party. Komedia (1950), w: idem, Cztery dramaty, przeł. W. Juszczak, red. przekładu i posłowie M. Heydel, Gdańsk 2016.

Garlej B., O (podstawowym) znaczeniu Ingardenowskiej kategorii konkretyzacji estetycznej, Kraków 2018.

Ingarden R., Dziatalność naukowa Kazimierza Twardowskiego, w: idem, Z badań nad filozofia wspótczesna, Warszawa 1963.

Intuicja i intelekt u H. Bergsona. Przedstawienie teorii i próba krytyki, tłum. M. Turowicz, w: idem, Z badań nad flozofiq wspótczesna, Warszawa 1963.

Ks. Konstanty Michalski. Uczony - filozof - cztowiek, „Tygodnik Powszechny. Katolickie Pismo Społeczno-Kulturalne"1947, nr 34 (127).

Lekcerważenie pamięci, „Muzeum. Czasopismo Pedagogiczne, Poświęcone Sprawom Wychowania, Nauczania i Organizacji Szkolnictwa"1938, R. LIII.

Leopold Blaustein - teoretyk radia i filmu, „Zeszyty Prasoznawcze”1963, R. IV, nr 3 (17).

Max Scheler, „Przegląd Warszawski” 1922, t. IV, nr 13.

Max Scheler (29.VIII.1874. - 19.V.1928.), „Przegląd Filozoficzny”1928, R. 31, z. IV.

Mścistaw Wartenberg, „Dziennik Polski” 1938, R. IV, nr 111.

O badaniach filozoficznych Edith Stein, w: E. Stein, O zagadnieniu wczucia, tłum. D. Gierulanka, J.F. Gierula, Kraków 1988.

O pytaniach esencjalnych, w: idem, Z teorii jezyka ifilozoficznych podstaw logiki, Warszawa 1972.

Przemówienie radiowe na stulecie urodzin Edmunda Husserla, w: idem, Z badań nad flozofia wspótczesna, Warszawa 1963.

Wspomnienie o prof. Zawirskim, „Dziennik Literacki” 1948, R. II, nr 18 (61).

Wspomnienie o Stanistawie Ignacym Witkierwiczu, w: Stanistaw Ignacy Witkiewicz. Cztowiek i twórca. Ksiegga pamiątkowa, red. T. Kotarbiński,J.E. Płomieński, Warszawa 1957.

Wykłady z etyki, wybrał, oprac. i wstępem poprzedził A. Węgrzecki, Warszawa 1989.

Zygmunt Eempicki jako teoretyk literatury, w: idem, Studia z estetyki, t. III, Warszawa 1970.

Korespondencja Izydory Dąmbskiej z Romanem Witoldem Ingardenem, listy przeczytali, przepisali, opracowali oraz wstępem poprzedzili R. Kuliniak, D. Leszczyna, M. Pandura, Ł. Ratajczak, Kęty 2018.

Korespondencja Romana Witolda Ingardena. Z dziejów „Studia Philosophica. Commentarii Societatis Philosophicae Polonorum", listy przeczytali, przepisali oraz wstępem poprzedzili R. Kuliniak, D. Leszczyna, M. Pandura, Ł. Ratajczak, Kęty 2018.

Korespondencja Romana Witolda Ingardena z Kazimierzem Twardowskim, listy z oryginałów przeczytali, przepisali, opracowali oraz wstępem poprzedzili R. Kuliniak, D. Leszczyna, M. Pandura, Kęty 2016.

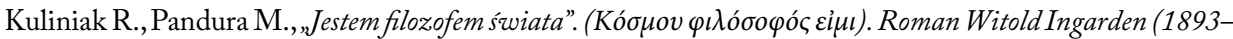
-1970). Częśś pierwsza: lata 1893-1938, Kęty 2019.

Migasiński J., Przyczynek do zarysu francuskiej fenomenologii pamięci. Trzy przyktady, „Fenomenologia. Pismo Polskiego Towarzystwa Fenomenologicznego" 2006, nr 4.

Mitość i nicość. Z Wtadystawem Stróżewskim rozmawia Anna Kostrzewuska-Bednarkiewicz, Warszawa 2017.

Sancipriano M., Le langage de la création esthétique dans la phénoménologie, „Analecta Husserliana” 1991, t. XXXIII.

Wartenberg M., Obrona metafizyki. Krytyczny wstęp do metafizyki, Kraków 1902. 
SŁOWA KLUCze: Ingarden Roman Witold, wspomnienie hołd, fenomenologia, poetyka, tekst okolicznościowy

\section{Beata Garlej}

\section{THE POETICS OF INGARDEN'S OBITUARIES HOMAGES PAID (NOT ONLY) TO PHENOMENOLOGISTS}

The article is dedicated to the poetics of obituaries homages by the Polish philosopher, ontologist and aesthetist, Roman Witold Ingarden. It centres on the issue of the extent to which the language of phenomenological perspective permeates the poetics of his occasional texts. The starting point is Ingarden's interpretation of memory as 'spiritual power', and therefore one that is not restricted exclusively to the didactical aspect, but, most importantly, one that facilitates ethical and moral development. The course of the reflection, as presented in the text, is therefore determined not exactly by philological analysis, but by an analysis concentrating on the composition scheme, which is a result of applying the phenomenological philosophy method.

KEY wORDs: Ingarden Roman Witold, obituary, homage, phenomenology, poetics, occasional text 